\title{
The Ethical Dimension in the New Public Management: Revisiting the Theory of Accountability, the Case of Public Finances in Morocco
}

\author{
Akhlaffou Mohamed \\ El Wazani Youssef \\ Souaf Malika \\ Lechheb Hafsa
}

Ibn Zohr University, National School of Business \& Management, Agadir, Morocco

doi: 10.19044/esj.2016.v12n31p440 URL:http://dx.doi.org/10.19044/esj.2016.v12n31p440

\begin{abstract}
In this paper, we focus on the positioning of the ethical theory of accountability and the relevance of the new public management in the integration of the ethical dimension in the management of public organizations and non-profit organizations. The objective is to show how the NPM and the theory of accountability incorporate the ethical dimension, and to what extent these two theories consider ethics in the construction process of public action, the sense and nonsense in public management and its relationship with the position of ethics in the management of public organizations. This will be done through a case study on the ethical dimension in the management of public finances in Morocco, proposing recommendations to make accountability in public finances more transparent and ethical.
\end{abstract}

Keywords: Ethics, accountability, new public management, meaning, public finance.

\section{Introduction}

The question of practices called "ethical" entered the news the field for ten years. Ethical reflection in business is at the heart of contradictions between economic and social logic. It is a reflection on the responsibility of the company in front of internal and external stakeholders. This notion of responsibility evokes the obligation to justify any act or decision according 
to moral norms and values, to respect ethical principles, such as accountability and accounts reporting.

Indeed, the improvement of public management necessarily requires a conduct dictated by compliance with ethical rules; because regulatory standards are insufficient to frame actions of public officials.

Work on public organizations and non-profit organizations notes managerial problems due to the lack of meaning in their management (Trosa and Bartoli, 2011). Poor internal mismanagement of public enterprises and the persistence of questionable practices in terms of effectiveness and efficiency are all handicaps affecting the implementation of an efficient management style. Therefore, questions remain about the contributions of theories in the field including the new public management and accountability.

Henceforth, we ask ourselves the question: how do the NPM and the accountability theory incorporate the ethical dimension? Do both theories consider ethics in the public action construction process? Sense and nonsense in public management, are they a configuration of the ethics position in the management of public organizations?

In this paper, we focus on the positioning of ethics in the accountability theory and on the relevance of the new public management in the integration of the ethical dimension in the management of public organizations and non-profit organizations. This will be done through a case study on the ethical dimension of the principle of accountability in the management of public finances in Morocco.

\section{The ethical dimension in the New Public Management: Definitions and Issues}

\subsection{The concept of ethics:}

The concept of ethics refers to the principles and rules laid down in terms of freedoms and constraints, it is directed towards the regulation of action and aims to make it more efficient and more orderly.

However, the Anglo-Saxon concept "ethics" has a broader meaning that includes both ethics and morality (Jobard, 1992). Beyond the original difference between the terms ethics of Greek origin and morality of Latin origin, some researchers make these concepts synonyms (Puel, 2000; Gueranger , 2009), while others consider that ethics is general in nature and that morality is more individual (Spiteri ,1993).

Ethics leads to thinking in terms of a utilitarian purpose, the welfare of the group ${ }^{1}$. On the entrepreneurial level, the first ethical charts were developed in the 1960s as a contract between society and the company in a more or less formalized way. The first relies on the second power to generate 
profits and realize production, but in return, the latter must be responsible to the community, especially in public administration.

\subsection{New Public Management (NPM)}

Hood defines NMP as follows: "all substantially similar administrative doctrines that dominated the bureaucratic reform program in many countries since the late 70" (Hood, 1991: 3-4). The NMP was born in the early 1980s in the United Kingdom and New Zealand, and is then deployed in most OECD countries. NPM is a new form of public management based on a culture of results, and that is the result of reforms that the public administration knew to address the problem of inefficient old management methods in the public sector; through a transposition of management methods and mechanisms of the private sector to the public sector.

Indeed, the characteristics of NMP are:

- Separation of strategic decision making under the political authority of operational management within the administration;

- The orientation of administrative activities and resource allocation based on the products and services to deliver rather than rules or procedures; instrument;

- Decentralization and the establishment of agencies as regulatory

- Abandonment of civil servant status and of promotion by seniority for a merit remuneration instead;

- The introduction of market mechanisms in the provision of goods and services of general interest;

- The logic of transparency on both the quality and costs of services;

- The search for efficiency in the use of public funds;

- Involvement of users in the definition and evaluation of public performance.

\section{The ethical dimension of the principle of accountability}

The promotion of public governance will necessarily requires the generalization of the principle of accountability throughout the state sphere. This principle means that the agent or civil servant has a responsibility to be accountable for his actions. The majority of public civil serbvants still receive their function as a reward rather than a burden to bear, that is why it is necessary to integrate the ethical dimension in the accountability theory.

Public administrations are obliged to impose on themselves a comprehensive and transparent accountability. Such accountability should show how the administration has fulfilled its mission and demonstrate that public funds were used efficiently and effectively to assess their performance. It constitutes an obligation of transparency of the employee to 
his superior in relation to the work performed. This accountability can be continued and materialized through regular monitoring or may be ad hoc via an evaluation. According G.Clotuche (2011), this accountability can be followed by rewards or penalties to encourage the desired behavior.

The principle of accountability would be helpful only if it is guided by a suitable value system; because this principle should not be based only on a set of legal and technical rules. Indeed, in an autonomy and accountability context, it appears essential that the civil servant reflects on the mission of his organization, its purposes and the values it carries.

It is in this sense that ethics must play an important role in the management of public affairs, and the civil servant must act in a spirit of ethical standards that apply to him and not according to a logic based on avoiding sanctions.

It is in this same sense that the affirmation of shared values by staff members of the public administration (ethics charter, code of ethics ... etc.), both internally and towards the citizens they serve, appears to be essential, not to add to the existing legal rules, but rather to help remember the principles upon which they are based.

\section{Ethics and Public Finance in Morocco:}

Public finances are a public law branch whose object is the study of the rules and operations relating to revenue and expenditure. Their purpose is the study of the legal, political and economic aspects of revenue and expenditure of the State. In Morocco, public finances have become a major instrument of public policy and a vital means for the government to guide and develop the economic and social life.

The new Constitution of Morocco aims to consolidate the rule of law, the consecration of the principles of separation of powers, strengthening good governance and the relationship between responsibility and accountability.

It is therefore necessary for good public financial governance that the management of public finances obeys ethical rules, based on the principles of integrity, transparency, accountability, and fairness. Moreover, regulatory standards are insufficient to give direction and supervise the actions of public officials, which explains this keen interest for ethics, which now appears as a value of equilibrium and regulation. It draws indeed in what is best in every person and cannot be reduced to a catalog of uniform requirements (Sbai El Idrissi, 2007). 


\section{Corruption and financial governance of public finances:}

Corruption is the misuse of a mandate or a position of power in favor of private interests. It ensures benefits to those who have resources of power, status, money or protection.

Consequences of corruption include: declining revenue and rising expenses of the state because of the diversion of resources, capital leakage and / or investment disincentives, unequal access and deterioration of public services, undermining democracy and even political destabilization.

The following formula summarizes corruption in four variables:

$\mathbf{C}=\mathbf{M}+\mathbf{D}-(\mathbf{T}+\mathbf{A})$

\section{$\mathbf{M}=$ Monopoles $\quad \mathbf{T}=$ Transparency \\ D = Discretionary Power $\mathbf{A}=$ Accountability}

For this, transparency and accountability must be enhanced in the fight against this scourge.

\section{An ethical and transparent accountability in the mnagement of public finances:}

The public administration in Morocco must impose a transparent accountability based on ethical standards and not only on technical and legal rules. For the principle of accountability to bear fruit, it must of course be based on a well founded system of ethics and on objective and transparent information: the only testimonial of assessed leaders is not enough. Indeed, it must demonstrate that public funds were used efficiently and effectively.

At the same time, an ethical accountability requires four conditions beforehand: accuracy of budgets, clarity of execution operations, accuracy of the accounts, and the integrity of agents.

Therefore, efforts must converge into programs supporting the morality of the action of agents that manage public finances, and selfaccountability must be encouraged, in order to make it comply with their obligations. It requires consistency between personal convictions and public action and implies self-control, integrity and the moral courage necessary so that the exercise of an activity is compatible with beliefs and convictions.

For such an ethical accountability, we suggested the following recommendations:

- A Promoting of transparency and of the obligation to accountability at all levels of responsibility;

- Strengthening control institutions (ICPC, Competition Council ...)

- An essential civic education that guarantee the respect of ethical values;

- Presenting the accounting data and the indicators (quantitative or qualitative) that measure the efficiency of the administration in the use of public funds; 
- Increased visibility and transparency of the internal control procedures within public agencies;

- Improved financial reporting (accountability, reporting during the preparation of the budget law and during its execution);

- Production and publication of specific budgets to the attention of citizens (easy to understand);

- Integration of the ethical dimension in the NPM, by revisiting the accountability theory;

\section{Conclusion:}

Ethics is a set of moral rules of conduct to be followed by all public agents, for the good governance of public action. Indeed, the promotion of public governance will necessarily require the generalization of the principle of accountability throughout the state sphere.

Work on public organizations and non-profit organizations is facing managerial problems due to the lack of meaning in their management (Trosa and Bartoli, 2011).

In this paper we addressed the positioning of ethics in the accountability theory and the relevance of the new public management in the integration of the ethical dimension in the management of public organizations and non-profit organizations.

It is in this sense, that it is necessary to incorporate the ethical dimension in accountability because the technical and regulatory rules are insufficient to guide the actions of public agents. In the field of public finance as in other areas, this ethical dimension therefore seems to have to be established by moral authorities, since public finances are an instrument of economic policy necessary for stimulating economic growth and human development. Ethics must spontaneously arouse accession, including in matters such as public finances, which are deemed technical but, in reality, can see their essential principles reduced to some ethical standards, such as transparency and integrity, with a complete and ethical accountability.

Improving the quality of public management inevitably requires the development of new forms of accountability based on ethical rules. That supposes the introduction of ethical assessment techniques in decision systems, in contexts of transparency that protect them from political or administrative pressures that may distort them; this also requires the circulation of more relevant information that ensures optimal communication between the administration, politicians and citizens.

\section{References :}

1. Annexe au Code Marocain de Bonnes Pratiques de Gouvernance d'Entreprise (2008). 
2. Bai, G. (2012). How Do Board Size and Occupational Background of Directors Influence Social Performance in For-profit and Non-profit Organizations? Evidence from California Hospitals.Journal of Business Ethics, 1-17.

3. Bartoli, A., Keramidas, O., \& Larat, F. (2012), Vers un management public éthique et performant. Revue française d'administration publique, (4), 629-639.

4. Charte d'Ethique du Contrôleur Financier.

5. De Bry, F. (2008). Concept d'éthique l'éthique au cœur du management. Management \& Avenir, (6), 102-114.

6. Deslandes, G. (2012). Le management éthique. Dunod.

7. Eberle, D., Berens, G., \& Li, T. (2013). The Impact of Interactive Corporate Social Responsibility Communication on Corporate Reputation.Journal of Business Ethics, 1-16.

8. El Idrissi, L. S. (2007). Intégrité, éthique et finances publiques au Maroc. Finance \& Bien Commun, (3), 74-80.

9. Eraly, A., \& Hindriks, J. (2007). Le principe de responsabilité dans la gestion publique. Reflets et perspectives de la vie économique, (1), 193-208.

10. Erhemjamts, O., Li, Q., \& Venkateswaran, A. (2012). Corporate Social Responsibility and Its Impact on Firms' Investment Policy, Organizational Structure, and Performance. Journal of Business Ethics, 1-18.

11. Göransson, M. (2010). La responsabilisation des hauts fonctionnaires aux différents niveaux de pouvoir. Courrier hebdomadaire du CRISP, (11), 7-83.

12. ICPC (2011), Bonne gouvernance entre situation actuelle et les dispositions de la nouvelle constitution de 2011, www.icpc.ma.

13. Kotler, P., \& Lee, N. (2008). Corporate social responsibility: Doing the most good for your company and your cause. Wiley. com.

14. Labelle, F. (2005). La performance sociétale organisationnelle comme convention sociale entre l'entreprise et son milieu: le cas d'Alcan au Saguenay-Lac-Saint-Jean (Doctoral dissertation, thèse de doctorat de gestion, UQAM, 2005. Retour).

15. Mazouz, B., Leclerc, J., \& Tardif, M. J. B. (2008). La Gestion Intégrée Par Résultats: Concevoir Et Gérer Autrement la Performance Dans L'administration Publique. PUQ .

16. Mercier, S. (1997). Une contribution à la formalisation de l'éthique dans les grandes entreprises, thèse de doctorat ès Sciences de Gestion, Université Paris IX Dauphine, septembre.

17. Michaud, Y. (2013). Qu'est-ce que le management responsable?: Confiance, décision, réflexivité. Eyrolles. 
18. Moussé, J. (2001). Ethique des affaires: liberté, responsabilité: le décideur face à la question éthique (pp. 12958770-18152). Dunod.

19. Pitelis, C. N. (2013).Towards a More 'Ethically Correct'Governance for Economic Sustainability.Journal of Business Ethics, 1-11.

20. Trosa, S. \& Bartlo, A. (2011), Le management par le sens, au service du bien public, Collection profession cadre service public - ScérénCNDP, $\mathrm{p}: 246$.

21. Van Doren, W., \& Lonti, Z. (2011). Contribution au débat sur la mesure de la performance de la gouvernance. Revue française d'administration publique, (3), 517-532. 